\title{
Antimony(V) chloride-promoted room temperature aromatization of 1,4-dihydropyridines in non-acidic solvent
}

\author{
Mirela Filipan-Litvić, ${ }^{a}$ Mladen Litvić, ${ }^{a *}$ Ivica Cepanec, ${ }^{a}$ and Vladimir Vinkovićb \\ ${ }^{a}$ BELUPO Pharmaceuticals, Inc., R\&D, Danica 5, 48000 Koprivnica, Croatia \\ ${ }^{b}$ Institute Ruđer Bošković, Bijenička c. 54, 10002 Zagreb, Croatia \\ E-mail: mladen.litvic@belupo.hr
}

\begin{abstract}
Antimony $(\mathrm{V})$ chloride acts as an efficient oxidant for the aromatization of 1,4-dihydropyridines in dichloromethane at room temperature. The products of high purity were isolated after simple work-up in high-excellent yield. Plausible non-typical two-electron transfer mechanism of the reaction was postulated to explain results obtained with 4-alkyl substituted 1,4-DHPs.
\end{abstract}

Keywords: 1,4-Dihydropyridines, pyridines, aromatization, antimony(V) chloride

\section{Introduction}

1,4-Dihydropyridines (1,4-DHPs) are one of the most important class of heterocyclic compounds due to their pharmacological activity as calcium antagonists or agonists. ${ }^{1}$ The 1,4-DHPs cause vasorelaxation by blocking voltage-operated calcium channel in smooth muscle cells and also by increasing NO release from the intact endothelium. ${ }^{2}$ Recently, some other pharmacological activities have been reported such as: antitumor, ${ }^{3}$ bronchodilating, ${ }^{4}$ antidiabetic, ${ }^{5}$ antiviral ${ }^{6}$ and antianginal. ${ }^{7}$ The 1,4-DHPs have also been extensively utilised as analogs of NAD(P)H coenzymes to study the mechanism and synthetic potential of various redox processes. ${ }^{8}$ The oxidation (aromatization) of 1,4-DHPs into corresponding pyridines is one of the main metabolic pathways of these drugs. This process is catalysed by the cyctochrome P450 (CYP) 3A4 isoform. ${ }^{9,10}$ Moreover, the products of aromatization (substituted pyridines) have found use in treatment of atherosclerosis. ${ }^{11}$ Consequently, this aromatization reaction continues to attract the attention of researchers for the discovery of mild and general oxidant to a wide variety of substituted 1,4-DHPs. Several oxidizing agents have been used for that purpose including metallic salts, ${ }^{12}$ non-metallic reagents ${ }^{13}$ among others. ${ }^{14}$ However, most of the methods suffer from low selectivity, harsch reaction condition, use of toxic and expensive reagents, corrosive solvents, tedious work-up, etc. Therefore, development of mild, more selective and practical method for this tranformation is still in demand. 
In continuation of our program toward development of more facile methods for the aromatization of 1,4-DHPs, ${ }^{15}$ we wish to report our new findings that overcome abovementioned difficulties of literature methods by using antimony(V) chloride $\left(\mathrm{SbCl}_{5}\right)$ as a mild, selective and efficient commercially available oxidant.

\section{Results and Discussion}

We began our studies with elements from 13-16 group of the periodic system. Our aim was to determine which elements from those groups are capable of reacting with 1,4-DHPs to form selectively substituted pyridines. In the literature, only Tl(III), ${ }^{16} \mathrm{Sn}(\mathrm{IV}){ }^{17}$ and $\mathrm{Pb}(\mathrm{IV}){ }^{15}$ have been described as convenient oxidants for the aromatization of 1,4-DHPs. From the results with $\mathrm{Bi}\left(\mathrm{NO}_{3}\right)_{3}{ }^{12 \mathrm{a}}$ and $\mathrm{BiONO}_{3},{ }^{18}$ it is not clear whether $\mathrm{Bi}(\mathrm{III})$ acts as an oxidant. It is more likely to expect that reaction take place with equilibrium amount of nitric acid formed by hydrolysis of the respective salt. The preliminary results of aromatization of model 1,4-DHP 1 with In(III), $\mathrm{Ge}(\mathrm{IV}), \mathrm{Sb}(\mathrm{V}), \mathrm{Se}(\mathrm{IV})$ and $\mathrm{Te}(\mathrm{IV})$ are presented in Table 1.

Table 1. Aromatization of 1,4-DHP 1 with selected higher-valent elements from 13 - 16 group of the periodic system

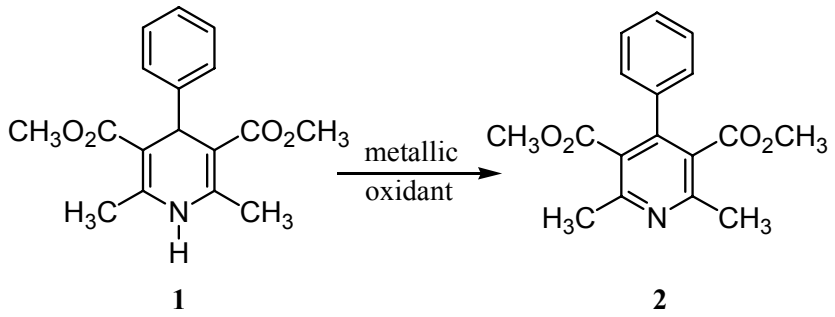

\begin{tabular}{ccccc}
\hline Entry & Oxidant $^{\mathrm{a}}$ & Solvent & Reaction time $[\mathrm{h}]^{\mathrm{b}}$ & ${\text { Conversion (Yield) }[\%]^{\mathrm{d}}}^{\mathrm{c}}$ \\
\hline 1 & $\mathrm{In}_{2} \mathrm{O}_{3}$ & $\mathrm{CH}_{3} \mathrm{COOH}$ & 20 & $100^{\mathrm{e}}(90)$ \\
2 & $\mathrm{GeCl}_{4}$ & $\mathrm{CHCl}_{3}$ & 480 & $100^{\mathrm{c}}(89)$ \\
3 & $\mathrm{GeCl}_{4}$ & $\mathrm{CH}_{3} \mathrm{CN}$ & 84 & $100^{\mathrm{c}}(80)$ \\
4 & $\mathrm{GeCl}_{4}$ & $\mathrm{CH}_{3} \mathrm{COOH}$ & 1080 & $97^{\mathrm{c}}(85)$ \\
5 & $\mathrm{SbCl}_{5}$ & $\mathrm{CH}_{2} \mathrm{Cl}_{2}$ & 48 & $100^{\mathrm{c}}(96)$ \\
6 & $\mathrm{SbCl}_{5}$ & $\mathrm{CH}_{3} \mathrm{COOH}$ & 21 & $92^{\mathrm{c}}$ \\
7 & $\mathrm{SeO}_{2}$ & $\mathrm{CHCl}_{3}$ & 72 & $98^{\mathrm{c}}$ \\
8 & $\mathrm{SeO}_{2}$ & $\mathrm{CH}_{3} \mathrm{COOH}$ & 5 & $100^{\mathrm{c}}(90)$ \\
9 & $\mathrm{SeCl}_{4}$ & $\mathrm{CHCl}_{3}$ & 0.25 & $-{ }^{\mathrm{f}}$ \\
10 & $\mathrm{TeO}_{2}$ & $\mathrm{CH}_{3} \mathrm{COOH}$ & 24 & $0^{\mathrm{e}}$ \\
11 & $\mathrm{TeCl}_{4}$ & $\mathrm{CHCl}_{3}$ & 24 & $0^{\mathrm{e}}$ \\
12 & $\mathrm{TeCl}_{4}$ & $\mathrm{CH}_{3} \mathrm{COOH}$ & 24 & \\
\hline
\end{tabular}

${ }^{\mathrm{a}}$ Stoichiometric amount. ${ }^{\mathrm{b}}$ Determined by TLC. ${ }^{\mathrm{c}}$ At room temperature. ${ }^{\mathrm{d}}$ Isolated yield. ${ }^{\mathrm{e}}$ At reflux temperature. ${ }^{\mathrm{f}}$ Less polar side-products are formed. 
The aromatization with stoichiometric amount of $\mathrm{GeCl}_{4}$ (Entries 2 and 3), $\mathrm{SbCl}_{5}$ (Entry 5) and $\mathrm{SeO}_{2}$ (Entry 8 ) smoothly proceeded at room temperature and the product was isolated in good-to-excellent yield. The most reactive salt was proved to be $\mathrm{SeCl}_{4}$ which rapidly reacted with 1 in $15 \mathrm{~min}$. but with very low chemoselectivity. The reaction with $\operatorname{In}_{2} \mathrm{O}_{3}$ took place only in acetic acid at reflux temperature with good chemoselectivity. Surprisingly, the aromatization with tellurium salts $\left(\mathrm{TeO}_{2}\right.$ and $\left.\mathrm{TeCl}_{4}\right)$ did not give even a trace of the product 2 even at reflux temperature of chloroform and acetic acid (Entries 10-12). From the obtained preliminary results we have decided to test in detail $\mathrm{SbCl}_{5}$ as cheap, non-toxic and easily accesible compound. In the literature $\mathrm{SbCl}_{5}$ has been primarly used as selective Lewis acid in many organic tranformations ${ }^{19}$ but its oxidation ability was almost neglected. The optimal amount of $\mathrm{SbCl}_{5}$ in aromatization of 1,4-DHP 2 was proved to be 2.1 equivalent and reaction was completed in $1 \mathrm{~h}$. These reaction conditions were used for the aromatization of substituted 1,4-DHPs and the results are summarized in Table 2.

Table 2. Aromatization of substituted-1,4-DHPs with $\mathrm{SbCl}_{5}$ in dichloromethane at room temperature

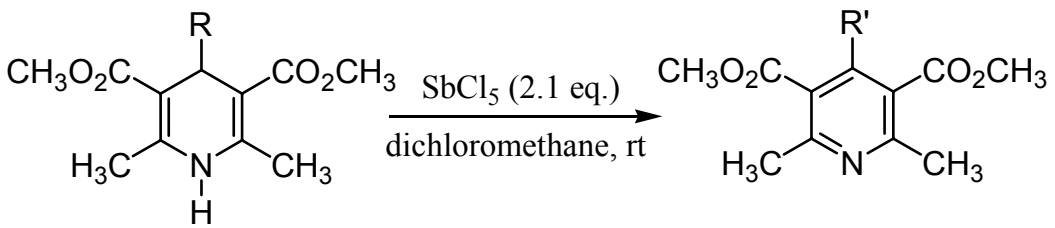

1, 3-11

2, 12-19

\begin{tabular}{|c|c|c|c|c|c|c|c|c|}
\hline \multirow[t]{2}{*}{ Entry } & \multirow{2}{*}{$\begin{array}{l}1,4- \\
\text { DHP }\end{array}$} & \multirow{2}{*}{$\mathrm{R}$} & \multirow{2}{*}{ Product } & \multirow{2}{*}{$\mathrm{R}^{\prime}$} & \multirow{2}{*}{$\begin{array}{l}\text { Time } \\
{[\mathrm{min}]}\end{array}$} & \multirow{2}{*}{$\begin{array}{c}\text { Yield } \\
{[\%]}\end{array}$} & \multicolumn{2}{|c|}{ m.p. $\left[{ }^{\circ} \mathrm{C}\right]$} \\
\hline & & & & & & & Found & Reported \\
\hline 1 & 1 & $\mathrm{Ph}$ & 2 & $\mathrm{Ph}$ & 60 & 96 & $134-136$ & $135-136^{20}$ \\
\hline 2 & 3 & $\mathrm{H}$ & 12 & $\mathrm{H}$ & 1 & 91 & $99-100$ & $100^{21}$ \\
\hline 3 & 4 & $\mathrm{CH}_{2} \mathrm{CH}_{3}$ & 12 & $\mathrm{H}$ & 360 & 90 & $99-100$ & $100^{21}$ \\
\hline 4 & 5 & $\mathrm{CH}\left(\mathrm{CH}_{3}\right)_{2}$ & 13 & $\mathrm{CH}\left(\mathrm{CH}_{3}\right)_{2}$ & 5 & $-{ }^{\mathrm{a}}$ & Oil & - \\
\hline 5 & 6 & $\mathrm{CH}_{2} \mathrm{Ph}$ & $14 / 12$ & $\mathrm{CH}_{2} \mathrm{Ph} / \mathrm{H}$ & 1 & $-{ }^{b}$ & $-^{\mathrm{c}}$ & - \\
\hline 6 & 7 & $o-\mathrm{ClC}_{6} \mathrm{H}_{4}$ & 15 & $o-\mathrm{ClC}_{6} \mathrm{H}_{4}$ & 60 & 90 & $70-71$ & $70^{12 \mathrm{c}}$ \\
\hline 7 & 8 & $m-\mathrm{CH}_{3} \mathrm{C}_{6} \mathrm{H}_{4}$ & 16 & $m-\mathrm{CH}_{3} \mathrm{C}_{6} \mathrm{H}_{4}$ & 60 & 95 & $93.5-95.5$ & - \\
\hline 8 & 9 & $p-\mathrm{OCH}_{3} \mathrm{C}_{6} \mathrm{H}_{4}$ & 17 & $p-\mathrm{OCH}_{3} \mathrm{C}_{6} \mathrm{H}_{4}$ & 60 & 92 & $114-116$ & $115-117^{12 j}$ \\
\hline 9 & 10 & 2-thienyl & 18 & 2-thienyl & 2 & 81 & $79-81$ & - \\
\hline 10 & 11 & 2-furyl & 19 & 2-furyl & 1 & 80 & $60-62$ & $\mathrm{Oil}^{22}$ \\
\hline
\end{tabular}

${ }^{\mathrm{a}}$ Isolated in low yield $(<5 \%)$ with decomposition products. ${ }^{\mathrm{b}}$ Isolated as a mixture with product of dealkylation 12 (85\% : 15\%, determined by HPLC). ${ }^{c}$ Mixture of viscous oil and crystals.

The main characteristics of the reactions are short reaction times (1-360 min), good-toexcellent yields (80-86\%) and high purities of crude products. Substituted aryl groups (Entries 
6-8) were well tolerated including highly reactive 2-thienyl and 2-furyl analogues $(\mathbf{1 0 , 1 1})$, which were almost instantly oxidised. The most interesting results was obtained with ethyl analogue 4 which was slowly but selectively dealkylated to give 12, while benzyl analogues 6 was only partially dealkylated giving a mixture of expected (non-dealkylated) and dealkylated products in a ratio 5.7 : 1.0 with small amount (15\%) of benzyl-chloride as dealkylation side product. Interestingly, isopropyl derivative 5 was selectively oxidised affording pyridine $\mathbf{1 3}$ in low yield. This is a first example of reversed dealkylation obtained during the aromatization of 4-alkyl-1,4DHPs. Usually, secondary and benzyllic substituents are easily dealkylated while primary alkyl groups remain intact. ${ }^{23}$ To explain this observation we have proposed a mechanism which is outlined in Scheme 1.
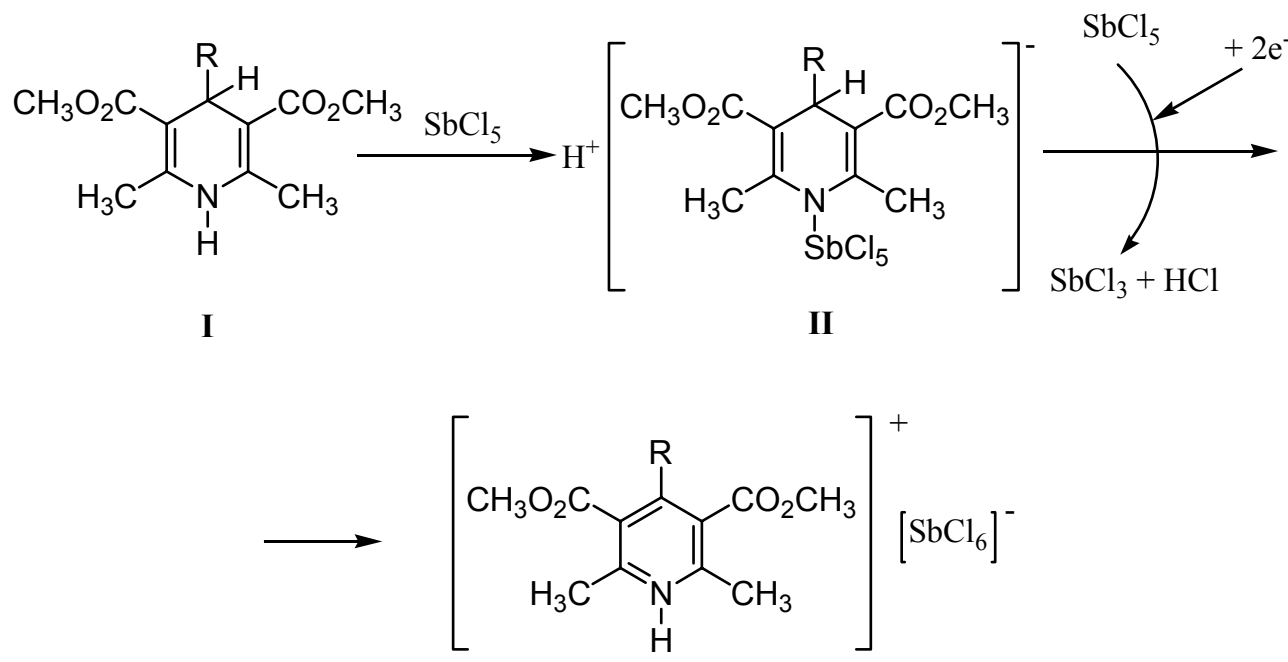

III

Scheme 1. Plausible mechanism for the aromatization of 1,4-DHPs with $\mathrm{SbCl}_{5}$.

As already mentioned, in the first step the complex II is formed by action of $\mathrm{SbCl}_{5}$ (Lewis acid) on the nitrogen center of 1,4-DHP I. This process deactivates one equivalent of the oxidant and second equivalent is needed to accelerate the reaction. In the next step, it is not likely to expect one-electron transfer from 1,4-DHP yielding 1,4-DHP radical-cation and $\mathrm{Sb}$ (IV) similarly to the mechanism with manganese triacetate mediated aromatization. ${ }^{121}$ It is rather to expect twoelectron transfer from 1,4-DHP ring forming more stable oxidation state of antimony (+3). By this process, one mole of $\mathrm{HCl}$ is evolved (noticed in reaction) and the product as hexachloroantimonate salt III is generated in a single step. This type of mechanism we have recently proposed in aromatization of 1,4-DHP with lead(IV) acetate. ${ }^{15}$ This mechanism was additionally proved in an enantioselective version of the reaction with tartarate modified $\mathrm{Pb}(\mathrm{IV})$ salts. ${ }^{24}$ Sterical hindrances between $\mathrm{SbCl}_{5}$ and bulky complex II are probably the main reason for non-typical behavior of alkyl substituents in the reaction. More sterically demanded isopropyl 
substituent, upon hydride abstraction gave, 13. In contrast, less sterical benzyl and ethyl groups were cleaved prior to $\mathrm{CH}$ bond.

The regeneration of antimony $(\mathrm{V})$ after the reaction is possible by the action of $30 \% \mathrm{H}_{2} \mathrm{O}_{2}$ in methanol at room temperature according to literature methods. ${ }^{25}$ The investigation of catalytic version of the method employing $\mathrm{H}_{2} \mathrm{O}_{2}$ and $\mathrm{O}_{2}$ as oxidants is in progress and the results will published in due course.

\section{Conclusions}

Antimony $(\mathrm{V})$ chloride acts as a mild, selective and efficient oxidant for the aromatization of 1,4DHPs to substituted pyridines in dichloromethane as a solvent at room temperature. Complete dealkylation of derivative with ethyl group was observed while derivative with benzyl group was only partially dealkylated. On the contrary, isopropyl derivative was selectively oxidised without a presence of dealkylation product. To explain this non-typical behavior plausible mechanism is proposed which include two-electron transfer from 1,4-DHP ring to $\mathrm{Sb}(\mathrm{V})$ cation.

\section{Experimental Section}

General Procedures. IR spectra were recorded on a Perkin-Elmer Spectrum One spectrometer. ${ }^{1} \mathrm{H}$ NMR and ${ }^{13} \mathrm{C}$ NMR were recorded on a Bruker 600 for $\mathrm{CDCl}_{3}$ solutions, shifts are given in ppm downfield from TMS as an internal standard. HPLC analyses were performed with a Thermo Separation Products (San Jose, USA) instrument equipped with vacuum degasser SCM 1000, quaternary gradient pump P 4000, autosampler AS 3000, scanning UV/VIS detector UV 3000 HR and ChromQuest 251 software. TLC analyses were performed on Merck's (Darmstadt, Germany) DC-alufolien with Kieselgel $60_{254}$. Melting points were determined using a Büchi B540 instrument. Elemental analyses were done in Central Analytical Service (CAS) at Ruđer Bošković Institute. Gram-scale samples of 1,4-DHPs were prepared by literature methods. ${ }^{26}$ The products of aromatization were characterized by a comparison with authentic samples (melting point) and their IR and NMR $\left({ }^{1} \mathrm{H},{ }^{13} \mathrm{C}\right)$ spectra. ${ }^{27,28}$

\section{General Procedures for the aromatization of 1,4-DHPs with $\mathrm{SbCl}_{5}$}

To a solution of 1,4-DHP $(1.0 \mathrm{mmol})$ in dichloromethane, $\mathrm{SbCl}_{5}(0.27 \mathrm{~mL}, 2.1 \mathrm{mmol})$ was added at once. The resulting solution was stirred at room temperature for the time indicated in Table 2. After that, to the reaction mixture was added water $(20 \mathrm{~mL})$ and solid $\mathrm{NaHCO}_{3}$ in small portions to $\mathrm{pH}>7$ (foaming!). The phases were separated, and the aqueous phase was additionally extracted with dichloromethane $(2 \times 10 \mathrm{~mL})$. The combined organic layers were dried over $\mathrm{Na}_{2} \mathrm{SO}_{4}$, filtered, and evaporated to dryness. The crude products were recrystallized from diisopropyl ether to give products of purity $>99 \%$. 


\section{Spectral and physical data for selected compounds}

16. Yield $93 \%$. Yellow crystals, mp 93.5-95.5 ${ }^{\circ} \mathrm{C} ; \mathrm{R}_{\mathrm{f}}\left(\mathrm{CH}_{2} \mathrm{Cl}_{2} / \mathrm{EtOAc}, 9: 1\right)=0.31$. IR $v=2959$, 2927, 1733, 1606, 1563, 1488, 1454, 1428, 1373, 1289, 1239, 1209, 1106, $1033 \mathrm{~cm}^{-1}$; ${ }^{1} \mathrm{H}$ NMR $\left(\mathrm{CDCl}_{3}\right): \delta=2.35(\mathrm{~s}, 3 \mathrm{H}, \mathrm{Me}), 2.59(\mathrm{~s}, 6 \mathrm{H}, \mathrm{Me}), 3.55(\mathrm{~s}, 6 \mathrm{H}, \mathrm{OMe}), 7.02-7.05(\mathrm{~m}, 2 \mathrm{H}), 7.16-$ $7.18(\mathrm{~m}, 1 \mathrm{H}), 7.23-7.28(\mathrm{~m}, 1 \mathrm{H}) ;{ }^{13} \mathrm{C} \mathrm{NMR}\left(\mathrm{CDCl}_{3}\right): \delta=21.2\left(\mathrm{C}_{6} \mathrm{H}_{4} \mathrm{CH}_{3}\right), 22.8\left(\mathrm{CH}_{3}\right), 52.0$ $\left(\mathrm{OCH}_{3}\right), 124.7,126.6,128.0,128.2,129.2$, 136.2, 137.8, 146.2, 155.3, 168.4 (CO). Anal. Calcd. for $\mathrm{C}_{18} \mathrm{H}_{19} \mathrm{NO}_{4}$ : C 68.99, $\mathrm{H}$ 6.11, $\mathrm{N}$ 4.47; found: C 68.8, $\mathrm{H}$ 5.9, $\mathrm{N} 4.3$.

18. Yield $81 \%$. Pale yellow crystals, mp $79.0-81.0^{\circ} \mathrm{C}, \mathrm{R}_{\mathrm{f}}\left(\mathrm{CH}_{2} \mathrm{Cl}_{2} /\right.$ EtOAc, 9:1) $=0.39$. IR v 2955, 2855, 1731, 1630, 1558, 1435, 1398, 1381, 1373, 1244, 1208, 1106, $1039 \mathrm{~cm}^{-1}$; ${ }^{1} \mathrm{H}$ NMR $\left(\mathrm{CDCl}_{3}\right) \delta 2.58\left(\mathrm{~s}, 6 \mathrm{H}, \mathrm{CH}_{3}\right), 3.68\left(\mathrm{~s}, 6 \mathrm{H}, \mathrm{OCH}_{3}\right), 7.04-7.07(\mathrm{~m}, 2 \mathrm{H}), 7.28-7.43(\mathrm{~m}, 1 \mathrm{H}),{ }^{13} \mathrm{C}$ NMR $\left(\mathrm{CDCl}_{3}\right) \delta 22.93\left(\mathrm{CH}_{3}\right), 52.46\left(\mathrm{OCH}_{3}\right), 127.27,127.78,128.47,135.84,138.42,145.11$, 155.51, 168.30 (CO). Anal Calcd. for $\mathrm{C}_{15} \mathrm{H}_{15} \mathrm{NO}_{4} \mathrm{~S}$ : $\mathrm{C} 59.00, \mathrm{H} 4.95, \mathrm{~N} 4.95, \mathrm{~S}$ 10.50. Found: $\mathrm{C}$ 59.11, H 5.01, N 4.99, S 10.41.

\section{Acknowledgements}

The authors wish to express their gratitude to the Belupo Pharmaceuticals Inc. for financial support of this research.

\section{References and Notes}

1. Grün, G.; Fleckenstein, A. Arzneim. Forsch. (Drug Res.) 1972, 22, 334.

2. Berkels, B.; Roesen, R.; Dhein, S.; Fricke, U.; Klaus, W. Cardiovasc. Drug Rev. 1999, 17, 179.

3. Tsuruo, T.; Iida, H.; Nojiri, M.; Tsukagoshi, S.; Sakurai, Y. Cancer Research 1983, 43, 2905.

4. Chapman, R. W.; Danko, G.; Siegels, M. I. Pharmacology 1984, 29, 282.

5. Malaise, W. J.; Mathias, P. C. F. Diabetologia 1985, 28, 153.

6. Krauze, A.; Germane, S.; Eberlins, O.; Sturms, I.; Klusa, V.; Duburs, G. Eur. J. Med. Chem. 1999, 34, 301.

7. Peri, R.; Padmanabhan, S.; Rutledge, A.; Singh, S.; Triggle, D. J. J. Med. Chem. 2000, 43, 2906.

8. Stout, D. M.; Meyers, A. I. Chem. Rev. 1982, 82, 223.

9. Böcker, R. H.; Guengerich, F. P. J. Med. Chem. 1986, 29, 1596.

10. Kudo, S.; Okumura, H.; Miyamoto, G.; Ishizaki, T. Drug. Metab. Dispos. 1999, $27,303$.

11. Bischhoff, H.; Angerbauer, R.; Bender, J.; Bischoff, E.; Faggiotto, A.; Petzinna, D.; Pfitzner, J.; Porter, M. C.; Schmidt, D.; Thomas, G. Atherosclerosis 1997, 135, 119. 
12. (a) Mashraqui, S. H.; Karnik, M. A. Synthesis 1998, 713. (b) Khadilkar, B.; Borkar, S. Synth. Commun. 1998, 28, 207. (c) Pfister, J. R. Synthesis 1990, 689. (d) Sabitha, G.; Kiran Kumar Reddy, G. S.; Reddy, Ch. S.; Fatima, N.; Yadav, J. S. Synthesis 2003, 1267. (e) Balogh, M.; Hermecz, I.; Mészáros, Z.; Laszlo, P. Helv. Chim. Acta 1984, 67, 2270. (f) Vanden Eynde, J. J.; Mayence, A.; Maquestiau, A. Tetrahedron 1992, 48, 463. (g) Zolfigol, M. A.; Sadeghi, M. M.; Mohammadpoor-Baltork, I.; Choghamarani, A. G.; Taqian-Nasab, A. Asian J. Chem. 2001, 13, 887. (h) Zolfigol, M. A.; Salehi, P.; Ghorbani-Choghamarani, A.; Safaiee, M.; Shahamirian, M. Synth. Commun. 2007, 37, 1817. (i) Vanden Eynde, J. J.; D’Ozario, R.; Van Haverbeke, Y. Tetrahedron 1994, 50, 2479. (j) Bagley, M. C.; Lubinu, M. C. Synthesis 2006, 1283. (k) Vanden Eynde, J. J.; Delfosse, F.; Mayence, A.; Van Haverbeke, Y. Tetrahedron 1995, 51, 6511. (1) Varma, R. S.; Kumar, D. Tetrahedron Lett. 1999, 40, 21.

13. (a) Kröhnke, F.; Ahrenhok, G. M.; Gross, K. F. J. Prakt. Chem. 1960, 11, 256. (b) Zolfigol, M. A.; Kiany-Borazjani, M.; Sadeghi, M. M.; Memarian, H. R.; Mohammadpoor-Baltork, I. Synth. Commun. 2000, 30, 2945. (c) Zolfigol, M. A.; Kiany-Borazjani, M.; Sadeghi, M. M.; Mohammadpoor-Baltork, I.; Memarian, H. R. Synth. Commun. 2000, 30, 3919. (d) Zolfigol, M. A.; Kiany-Borazjani, M.; Sadeghi, M. M.; Mohammadpoor-Baltork, I.; Memarian, H. R. Synth. Commun. 2000, 30, 551. (e) Ortiz, M. E.; Núñez-Vergara, L. J.; Squella, J. A. Pharm. Res. 2003, 20, 292. (f) Chavan, S. P.; Dantale, S. W.; Kalkote, U. R.; Jyothirmai, V. S.; Kharul, R. K. Synth. Commun. 1998, 28, 2789. (g) Cai, X.-hua; Yang, H.-jun; Zhang, G.-lin Can. J. Chem. 2005, 83, 273. (h) Panchgalle, S. P.; Choudhary, S. M.; Chavan, S. P.; Kalkote, U. R. J. Chem. Res. (S) 2004, 550.

14. (a) Mashraqui, S. H.; Karnik, M. A. Tetrahedron Lett. 1998, 39, 4896. (b) Nakamichi, N.; Kawashita, Y.; Hayashi, M. Org. Lett. 2002, 4, 3955. (c) Nakamichi, N.; Kawashita, Y.; Hayashi, M. Synthesis 2004, 1015. (d) Zolfigol, M. A.; Choghamarani, A. G.; Shahamirian, M.; Safaiee, M.; Mohammadpoor-Baltork, I.; Mallakpour, S.; Abdollahi-Alibeik, M.Tetrahedron Lett. 2005, 5581. (e) Anniyappan, M.; Muralidharan, D.; Perumal, T. Tetrahedron 2002, 58, 5069. (f) Mao, Y.-Z.; Jin, M-Z.; Liu, Z.-L.; Wu, L.-M. Org. Lett. 2000, 2, 741.

15. Litvić, M.; Cepanec, I.; Filipan, M.; Kos, K.; Bartolinčić, A.; Drušković, V.; Tibi, M. M.; Vinković, V. Heterocycles 2005, 65, 23.

16. (a) Hashemi, M. M.; Zakeri, M. S.; Arianfar, S. Iran. J. Chem. \& Chem. Eng. 2003, 22, 9. (b) Momeni, A. R.; Massah, A. R.; Naghash, H. J.; Aliyan, H.; Solati, S.; Sameh, T. J. Chem. Res. (S) 2005, 4, 227.

17. Jain, S. M.; Kant, R.; Dhar, K. L.; Singh, S.; Singh, G. B. Ind. J. Chem. 1990, $29 B, 277$.

18. Rajanarendar, E.; Ramesh, P.; Srinivas, M.; Ramu, L.; Mohan, G. Synth. Commun. 2006, 36, 665.

19. (a) Huang, A.; Liu, X.; Li, L.; Wu, X.; Liu, W.; Liang, Y. Adv. Synth. Catal. 2004, 346, 599.

(b) Kobayashi, S.; Tamura, M.; Mukaiyama, T. Chem. Lett. 1988, 91.

20. Zeynizadeh, B.; Dilmaghani, K. A.; Roozijoy A. J. Chem. Res. 2005, 657. 
21. Chavan, S. P.; Kharul, R. K.; Kalkote, U. R.; Shivakumar, I. Synth. Commun. 2003, 33, 1333.

22. Varma, R. S.; Kumar, D. Tetrahedron Lett. 1999, 40, 21.

23. Heravi, M. M.; Behbahani, F. K.; Oskooie, H. A.; Shoar, R. H. Tetrahedron Lett. 2005, 46, 2775.

24. Litvić, M. Enantioselective and Diastereoselective Preparations of 1,4-Dihydropyridines, Doctoral thesis, University of Zagreb, 2004.

25. (a) Leuz, A. K., Hug, S. J., Wehrli, B., Johnson, C. A. Environ. Sci. Technol. 2006, 40, 2565. (b) Knör, G. Inorg. Chem., 1996, 35, 7916.

26. Litvić, M.; Cepanec, I.; Vinković, V. Heterocycl. Commun. 2003, 9, 385.

27. Filipan-Litvić, M.; Litvić, M.; Cepanec, I.; Vinković, V. Molecules 2007, 12, 2546.

28. Filipan-Litvić, M.; Litvić, M.; Cepanec, I.; Vinković, V. Tetrahedron 2008, submitted for publication. 